\title{
Isolation Of Pectobacterium Carotovorum, Identification With 16s Rrna, Phytase Activity And Characterization Of The Bacteria
}

\section{Kağan Tolga CiNiSLi}

Ataturk Universitesi Ziraat Fakultesi

Safa Mustafa KILIÇ

Ataturk Universitesi Ziraat Fakultesi

Sevda Uçar

Ataturk Universitesi Ziraat Fakultesi

Emre CANCA

Ataturk Universitesi Ziraat Fakultesi

Neslihan dikbaş ( $\nabla$ neslidikbas@atauni.edu.tr)

Ataturk Universitesi Ziraat Fakultesi https://orcid.org/0000-0002-6093-162X

Research article

Keywords: Pectobacterium carotovorum, 16S rRNA, Phytase, Characterization

Posted Date: December 12th, 2019

DOI: https://doi.org/10.21203/rs.2.18716/v1

License: (9) This work is licensed under a Creative Commons Attribution 4.0 International License. Read Full License 


\section{Abstract}

Background: Phytases can be produced by animals, plants and microorganisms. However, the most promising ones for commercial use and biotechnological applications are those of microbial origin. Phytases are also used in the preparation of myo-inositol phosphates in the food industry, soil remediation and in the paper industry. Biotechnology, along with the increased use of phytase enzymes, is a highly effective technology that is used today and will be used in the future to produce these enzymes and improve their properties.

Results: The aim of this study was to conduct the molecular identification of Pectobacterium carotovorum strains isolated from lettuce to produce phytase from a new microbial source and the characterization of the enzyme. The activity and characterization of the phytase obtained from the bacterium was carried out. Isolation of strains was carried out following incubation at $26^{\circ} \mathrm{C}$ for 48 hours using Nutrient agar (Oxoid). The identification was performed using the 16S rRNA method. The phytase produced from Pectobacterium carotovorum showed the best activity at $\mathrm{pH}$ 8.0. The optimum temperature of the phytase obtained from Pectobacterium carotovorum was $60^{\circ} \mathrm{C}$.

Conclusions: In this study, enzymatic activity of phytase was investigated in Pectobacterium carotovorum for the first time. The results showed that it can be used in the industry due to the characteristics of the enzyme produced by Pectobacterium carotovorum.

Keywords: Pectobacterium carotovorum, 16S rRNA, Phytase, Characterization

\section{Background}

The term "Biotechnology" can single-handedly explain what biotechnology means. Biology explains its relation to living organisms, while technology means shedding light to existing or emerging problems and developing useful products. Accordingly, biotechnology means using living organisms to shed light to problems and develop more useful products [1]. The application areas of biotechnology are divided into five fields comprising medical, agricultural, food, animal, environmental and industrial biotechnology [2].

In microbial biotechnology, the production of enzymes and organisms that are used in the production of various foods, facilitation of processing and more efficient disposal of industrial wastes has become possible with the manipulation of microorganisms such as bacteria and yeast. The vast number of bacteria and other microorganisms allows various potential biotechnological applications. Microbial biotechnology is a dynamic field that generates a wide range of new applications [3]. The advantages of bacteria including their rapid growth, easy and controlled culture in a small area and simpler structure compared to eukaryotes facilitate their use in the common fields of genetics and biochemistry [4].

Pectobacterium carotovora subsp. carotovora is a phytopathogen bacterium that causes soft rot in many economically valuable plant varieties. [5]. Pectobacterium carotovora subsp. carotovora causes one of the most destructive vegetable diseases worldwide (ECC). Pectobacterium carotovorum subsp. 
Brasiliense causes serious damage to potatoes and other vegetables due to black spot and soft rot diseases. When the differences between isolated species and subspecies are considered, Pectobacterium, which are similar to other species from the Enterobacteriaceae family that cause soft rot in plants, are facultative anaerobic, Gram (-), rod-shaped bacteria that have multiple flagella. In the studies, all isolates of the species (P. carotovora. subsp. carotovora, P. carotovora. subsp. atroseptica, P. carotovora. subsp. betavasculorum, P. carotovora. sp. wasabiae, P. carotovora. subsp. odorifera) were determined to be catalase positive and oxidase negative and have the ability to carry out glucose fermentation, reduce nitrate to nitrite, produce $B$-galactosidase and $\mathrm{H}_{2} \mathrm{~S}$ and use L-arabinose, D-galactose, D-glucose, glycerin, D-mannose, D-ribose and sucrose, do not have the ability to produce urease and have the ability to produce acid from adonitol. Majority of the isolates can use L-rhamnose and D-mannitol but lack the ability to use dextrin. The Pectobacterium species in this group cannot be tested using every test used for Enterobacteriaceae and, thus, an ambiguity emerges in their taxonomy. The general methods used in the isolation of phytopathogen bacteria from soil and plant samples can also be used for these bacteria. Enriched or selective media should be used in the isolations from rotten plant tissues and soils [6].

A new standard for the identification of the bacteria was developed in the $1980 \mathrm{~s}$. We have come to understand that the comparison of certain regions of the genetic codes of bacteria can help determine the phylogenetic similarity between bacteria $[7,8]$. The genes in the bacteria genome used for this purpose include 5S, 16S and 23S rRNA and the regions between these genes. Today, the most commonly used DNA region in the classification of bacteria is the $16 \mathrm{~S}$ rRNA gene region $[9,10,11]$. 16S rRNA gen sequence region is around 1550 base pairs (bp) long and consists of hypervariable and conserved regions. Using the $500 \mathrm{bp}$-long region is more cost-friendly and applicable and, thus, the $500 \mathrm{bp}$-long region is widely used in sequence analyses. 16S rRNA gene sequence analysis steps comprise DNA isolation, $\mathrm{PCR}$, purification, sequence cycle, sequence analysis, evaluation of the electropherogram and data analysis, respectively [12].

Enzymes have an important role in bacteria metabolism and various enzyme systems are needed for metabolic activity. Enzymes are catalyzer activators, i.e. has an accelerating effect on a reaction. Reactions can start without enzymes. Enzymes allow a significant amount of freedom for substrates. They show better activity under optimum $\mathrm{pH}$ and temperature conditions. The purity of industrial enzymes is usually low and, thus, their cost is lower, whereas scientific, analytic and medical enzymes have high purity and, thus, cost more.

Phytase (myo-inositol hexakisphosphate phosphohydrolase) catalyzes the hydrolysis of myo-inositol hexakisphosphate (phytic acid) to inorganic mono phosphate, reduced myo-inositol phosphates and, in many cases, free myo-inositol. There are basically two phytase enzymes: 3-phytase (E.C. 3.1.3.8) and 6phytase (E.C. 3.1.3.26). This classification is based on the first phosphate group the enzyme attaches to. 3-phytase is reactive for microorganisms and 6-phytase is reactive for plants [13]. Phytases catalyze the gradual removal of phosphate groups from the myo-inositol ring of phytate. These enzymes can be widely found in nature and more than 2000 soil isolates have been reported. According to their catalytic mechanisms, phytases can be called histidine acid phytases, cysteine phytases and purple acid phytases 
[14]. Although phytase was detected in plants, microorganisms and some animal tissues, recent studies have shown that microbial phytase yielded successful results in biotechnological applications [15. 16].

The study investigates the molecular identification of the P. carotovorum strain that was isolated from lettuce and procured from the Agricultural Biotechnology Culture Collection, phytase production from a new microbial source and characterization of phytase.

\section{Results}

In the study, the stock culture of the bacteria strain No. M7 available in the Enzyme and Microbial Biotechnology Science Department was used.

\subsection{Morphological Properties of the Microorganism}

Certain morphological properties of the isolate were examined. The sizes, endospore formation and Gram properties of the isolates were determined. Table 1 shows the results obtained for the morphological properties of the isolates.

Table 1

Morphological properties of P. carotovorum

\begin{tabular}{|c|c|c|c|}
\hline \multirow[t]{2}{*}{ Identification results } & \multirow[t]{2}{*}{ Cell Morphology } & \multicolumn{2}{|l|}{ Sizes } \\
\hline & & Diameter $(\mu \mathrm{m})$ & $\operatorname{Size}(\mu \mathrm{m})$ \\
\hline P. carotovorum subps. carotovorum & Rod & $0.5-0.6$ & 2 \\
\hline \multirow[t]{2}{*}{ Endospore } & Gram Properties & & \\
\hline & $\mathrm{KOH}$ & \multicolumn{2}{|c|}{ Gram Staining } \\
\hline- & - & \multicolumn{2}{|l|}{-} \\
\hline
\end{tabular}

In the investigation of the culture properties of the bacteria, the results were obtained when mature colonies of each isolate were formed in the agar medium (Nutrient agar). Table 2 shows the culture properties of the isolates in detail. Furthermore, Fig. 1 shows the colony and micron morphologies. The bacteria were isolated using streak plate method. Pure colony structures in the culture were examined and the pure colonies were used in further studies. 
Table 2

Properties of the P. carotovorum culture

\begin{tabular}{|llll|}
\hline Isolation Results & Colony Shape & Colony Color & Colony consistency \\
\hline P. carotovorum & Oval & Cream & Dry \\
\hline
\end{tabular}

\subsection{Determination of Some Biochemical Properties}

To support the identification with the molecular method, some biochemical tests were performed to obtain a precise identification. Table 3 shows the biochemical test results.

Table 3

Some biochemical test results of P. carotovorum

\begin{tabular}{|c|c|c|c|c|c|c|}
\hline Tests & $\begin{array}{l}\text { Citrate } \\
\text { test }\end{array}$ & $\begin{array}{l}\text { Indole } \\
\text { Test }\end{array}$ & $\begin{array}{l}\text { Phosphatase } \\
\text { Test }\end{array}$ & $\begin{array}{l}\text { Catalase } \\
\text { Test }\end{array}$ & $\begin{array}{l}\mathrm{KOH} \\
\text { Test }\end{array}$ & $\begin{array}{l}\text { Gram } \\
\text { Staining Test }\end{array}$ \\
\hline $\begin{array}{l}\text { P. carotovorum subps. } \\
\text { carotovorum }\end{array}$ & + & - & - & + & - & - \\
\hline
\end{tabular}

\subsection{Identification of P. carotovorum with the Molecular Method}

\subsubsection{DNA isolation results}

The genomic DNA isolation from the P. carotovorum isolate was carried out by following the protocol described in Sect. 3.2.5.a with no modification. Figure 2 shows the DNA isolation results.

\subsubsection{Gel image of the PCR results}

The PCR reactions that were carried out using the genomic DNA obtained from the P. carotovorum isolate yielded PCR products of desired sizes of 1400-1500 bp. Figure 3 shows the results. The marked region indicates $1400 \mathrm{bp}$ on the marker.

\subsubsection{Sequence analysis results}

Gene sequencing was carried out to confirm whether the PCR result was the 16S rRNA gene region. Figure 4 shows the sequences obtained by sequence analysis. The purpose of the tree is to show the relationship between close species and similarities between the samples that were determined to be species and their subspecies. 
The tree shown in Fig. 5 was obtained from NCBI and the accession number was given. The examination of Section A revealed three systematic main groups. Pectobacterium atrosepticum was the main taxon and identified as the outgroup. There were major similarities between the outgroup and other groups. The second important group was Pectobacterium carotovorum, the subject of the article. These serve as two examples of sister taxa. The group showed a high similarity. The other group is currently called Erwinia in mass. They had a high similarity among each other. E. persicinus and E. rhapontici were identified as different species and showed a similarity of $94 \%$ and, thus, had a higher similarity even when compared to their subspecies.

\subsection{Phytase Activity Results}

The activity of isolated and identified P. carotovorum was measured at different temperature and $\mathrm{pH}$ values and the results are given below.

\subsubsection{Optimum pH results for phytase}

Measurements were carried out to determine the optimum $\mathrm{pH}$ for phytase that was produced and purified from P. carotovorum. For optimum $\mathrm{pH}, 10$ different $\mathrm{pH}$ values ranging from $\mathrm{pH} 2.0$ to $\mathrm{pH} 11.0$ were investigated. For $\mathrm{pH}$ 2.0-6.0, acetate, for $\mathrm{pH} 7.0-9.0$, Tris $\mathrm{HCl}$ and for $\mathrm{pH} 10.0-11.0$, carbonate were used as buffers. The activity of the enzyme was measured using the results and "Activity-pH" graphs were drawn. Figure 6 shows the results.

\subsubsection{Optimum temperature results for the phytase obtained from P. carotovorum}

Measurements were carried out to determine the optimum temperatures for phytase that was produced and purified from P. carotovorum. Its activity was calculated using the results and the "Activity- ${ }^{\circ} \mathrm{C}$ " graphs were drawn. The results showed that the optimum temperature for the phytase obtained from $P$. carotovorum was $60^{\circ} \mathrm{C}$. Figure 7 shows the optimum temperature results for the phytase obtained from P. carotovorum.

\section{Discussion}

The individual morphologies of bacteria can only be examined under a microscope due to their small sizes. For this purpose, the pure preparations of the bacteria grown in liquid or agar media are stained with specific dyes. In microscopic examinations, the properties of bacteria such as size, endospore formation and staining (Gram (-) or (+), vb.) are examined $[17,18]$ P. carotovorum is a rod-shaped, nonendospore-forming, Gram (-) bacterium with a diameter of $0.5-0.6 \mu \mathrm{m}$ and size of $2 \mu \mathrm{m}$. The isolates are inoculated into agar media either with spot or streak plate isolation methods and, then, colony formation is waited; then, colony morphology is examined under a microscope to determine their appearance from above, height, edge shape and color [19]. The colony structure of P. carotovorum is oval, cream-colored 
and dry. Certain biochemical tests were carried out for P. carotovorum subps. carotovorum. Our results agree with the results obtained in previous studies [6]. The results showed that P. carotovorum subps. carotovorum tested positive for citrate and catalase and negative for indole and phosphatase. The bacteria were Gram (-) in terms of cell wall structure.

The methods used for identification and characterization can also be classified as conventional and molecular methods [20]. Molecular methods were developed based on the changes stemming from the contents, diversity and ratios of the macromolecules that form microorganisms. Molecular studies use carbohydrates, lipids, proteins and genetic materials (DNA and RNA) as the main materials and identify and characterize microorganisms with the help of one of these materials or their combinations. The sequence analysis of ribosomal operons is the most commonly used method to determine the phylogenetic relationship between organisms $[21,22,23,24,25,26,27]$.

In the study, phytase activity of P. carotovorum, which is used in various areas, temperature and $\mathrm{pH}$ values that can affect phytase activity and optimum $\mathrm{pH}$ and temperature values were investigated. To determine the optimum $\mathrm{pH}$ of the phytase purified from $\mathrm{P}$. carotovorum, activity measurements were carried out in the $\mathrm{pH}$ range of 2.0-11.0. For $\mathrm{pH} 2.0-6.0,0.1 \mathrm{M}$ acetate buffer, for $\mathrm{pH} 7.0-9.0,10 \mathrm{mM}$ Tris/ $\mathrm{HCl}$ buffer and for $\mathrm{pH} 10.0-11.0,10 \mathrm{mM}$ carbonate buffer were used to measure the activity of the enzyme with spectrophotometry. The phytase that was extracellularly produced and purified from $\mathrm{P}$. carotovorum had the highest activity at $\mathrm{pH} 8.0$ [28]. Since there were no previous studies on phytase from P. carotovorum, the results of the study were compared by using the activities of phytases from other bacteria species as reference. Tran et al. [29] found that the optimum temperature for the Bacillus Sp. MD.2 strain was $70{ }^{\circ} \mathrm{C}$. In their study, In their study, Erkan [30] determined that the optimum pH for Bacillus subtilis was 6.5 .

The study is an important contribution to the literature as it is the first study on phytase production from P. carotovorum. There were no studies on phytase production from P. carotovorum in the literature. With phytase production from $\mathrm{P}$. Carotovorum, we are of the opinion that the study will both add to biotechnology in terms of its R\&D potential and add diversity to global enzyme industry in terms of production. The phytase activity of P. carotovorum differs depending on temperature. In their study, Tran et al. [29] found that that the optimum temperature for the Bacillus Sp. MD.2 strain was $70^{\circ} \mathrm{C}$. Erkan [30] determined the optimum temperature for Bacillus subtilis as $60^{\circ} \mathrm{C}$. Since there were no previous studies on the phytase activity of P. carotovorum, we were not able to compare the optimum temperature of $60^{\circ} \mathrm{C}$ as found in our study to the literature. The lowest activity was measured at $20^{\circ} \mathrm{C}$. Phylogenetic tree was drawn to determine the position of Pectobacterium carotovorum on the tree. Finally, three systematic main groups were generated and our bacteria were highly similar to these groups. In conclusion, in the study, the optimum $\mathrm{pH}$ of $\mathrm{P}$. carotovorum was determined to be 8.0 , while it had the lowest activity at $\mathrm{pH}$ 4.0. Optimum temperature was found to be $60^{\circ} \mathrm{C}$, while the lowest activity was measured at $20^{\circ} \mathrm{C}$. The phytase activity of P. carotovorum was measured for the first time. The results and the cultural adaptation of the bacteria indicated that, in terms of its production, phytase can be introduced to 
technology. Due to the characteristic properties of the enzyme produced by the bacteria, our results support the idea that the enzyme can be used more efficiently and widely in the industrial areas.

\section{Material And Method}

\subsection{Inoculation of bacteria from the stock culture}

The stock culture was removed from $-80^{\circ} \mathrm{C}$ and kept at room temperature until thawing was completed. The culture was inoculated on nutrient agar using the three-phase inoculation method and incubated at $26^{\circ} \mathrm{C}$ for 3 days. The experiment was continued when bacteria growth reached a certain level.

\subsection{Determination of morphological properties}

The individual structures of bacteria can only be determined using microscopes, since bacteria are too small in size. Thus, the pure bacteria preparations in agar or liquid medium are examined using specific dyes. In the microscopic examinations, properties such as the sizes, endospore formation and staining (Gram (-) or (+), etc.) of bacteria are examined[18, 19]

a. Determination of cell morphology: Samples were prepared from each isolate and simple staining was carried out with crystal violet. The results were examined under a microscope $[31,18]$.

b. Determination of cell sizes: Cell sizes of the isolates from the preparations that were stained with simple or negative staining were measured by an ocular micrometer using immersion objective [31, 32]. 4.3. Determination of the properties of the culture The pure cultures of bacteria in agar and liquid medium were used in the determination of the properties of bacteria culture.

The isolates were inoculated into agar medium with either spot or streak plate isolation methods to allow colony formation. The colony morphology was examined under a microscope and their appearance from above, edge shape and color were determined [19].

Bacteria can reproduce by forming pellicle at the top and sediment or granules at the bottom. The isolates were inoculated into nutrient broth-containing tubes to determine the properties of the culture in liquid media [17].

4.4. Application of some biochemical tests

4.4.a. Catalase test

The test was used to determine whether catalase was present in the isolates. Catalase is present in facultative and aerobic microorganisms. Catalase converts hydrogen peroxide $\left(\mathrm{H}_{2} \mathrm{O}_{2}\right)$ occurring due to respiration into water and oxygen. For the test, a loopful of the 48-h culture was collected and one drop of $5 \% \mathrm{H}_{2} \mathrm{O}_{2}$ was added to observe bubble formation. Bubble formation showed that the test was positive [19].

4.4.b. Citrate test 
The test is used to determine the ability of microorganisms to use citrate as the carbon source and ammonium salts as the nitrogen source and identify the genera and species of bacteria. The degradation of citrate (citrate metabolism) by bacteria is carried out by their enzyme systems.

After dilution with physiological water or buffer, the pure cultures to be treated were inoculated into the media and the tubes were incubated at $37^{\circ} \mathrm{C}$ for 2-7 days. Inoculation with needle on the Christensen medium was carried out and the needle was also streaked on the slant surface. No sign of growth in the Simmons citrate medium after an appropriate amount of incubation time and a persistently green medium indicate negative reaction, while growth and dark blue color along the inoculation line indicate positive reaction. No color change in Christensen citrate sulfide medium (the light color remains) indicates negative reaction, while observing growth and pink-red color formation along the inoculation line indicate a positive reaction [6].

\section{4.c. Indole test}

The test is used to examine the indole production of microorganisms by the degradation of tryptophan, an amino acid. After inoculation into a liquid medium or peptone-containing water, the microorganisms were incubated at $37^{\circ} \mathrm{C}$ for $1-5$ days. A total of $0.5 \mathrm{ml}$ kovacs (or Ehrlich) was added to the cultures and thoroughly stirred. Formation of a red ring at the top of the tubes indicates a positive reaction (indole formation). Presence of a yellowish ring indicates that indole formation did not occur (negative indole test). The color is due to the pyrroles in indole [6].

\section{4.d. Phosphatase test}

The test is used to determine the presence of phosphatase especially the phosphatase synthesized by staphylococcus (coagulase positive). Microorganism cultures were inoculated into phenolphthalein phosphate agar and incubated at $37^{\circ} \mathrm{C}$ for 1-2 days. At the end of this period, the colonies were exposed to ammonia vapor ( $1 \mathrm{ml} \mathrm{NH} \mathrm{H}_{4} \mathrm{OH}$ is put on the lid of the petri dish and culture is closed upside down). If a liquid medium is used, one drop of sodium hydroxide is dropped on the tubes. Red coloration in the colonies or tubes indicates a positive reaction. No change in color is observed if the reaction is negative [6].

\section{4.e. Determination of Gram properties}

The test was used to determine the differences between the cell walls of the isolates. Two different methods can be used for this purpose.

In the first method, 1-2 drops of $3 \% \mathrm{KOH}$ solution is dropped on the microscope slide. Then, the bacteria collected with a loop is mixed with the $\mathrm{KOH}$ solution for $5-10$ seconds and the loop is lifted up. If the microorganism is Gram (-), the peptidoglycan layer in the cell wall has fewer layers and does not contain teichoic acid and thus, is easily disintegrated by $\mathrm{KOH}$ and cytoplasm and cell content are released. This leads to viscous stretching. While in Gram (+) bacteria, $\mathrm{KOH}$-bacteria mixture is an aqueous liquid and no stretching is observed when the loop is lifted up [19].

A drop of pure water is dropped on the microscope slide; then, a loopful of the bacteria that were grown on the medium for 24 hours is thoroughly streaked and fixed by fire. The preparation is first treated with crystal violet for 1 minute and rinsed with pure water for 30 seconds; then, it is treated with Lugol for 1 minute and rinsed with $96 \%$ ethyl alcohol. The preparation is re-rinsed with pure water and finally stained 
with safranin. The preparation is washed and dried and, then, examined under a microscope. Gram (+) bacteria are purple colored, Gram (-) bacteria are pink colored [33].

4.5. Molecular Identification of the Microorganism

4.5.a. DNA isolation from bacteria isolates

The isolation of the isolate DNAs was carried out using a DNA isolation kit (Qiagen) by following the instructions of the manufacturer.

The steps include;

1- A loopful of the bacteria grown in nutrient agars was collected into sterile Eppendorf tubes.

2- To the tubes, $200 \mu$ l Lysozyme + TrisHCL solution was added.

3- The mixture was thoroughly vortexed to obtain a homogenous dissolution.

4- The vortexed mixtures were incubated at $37^{\circ} \mathrm{C}$ for 45 minutes. During this period, vortex was repeated every 15 minutes.

5 - At the end of incubation, the samples were centrifuged at $12000 \mathrm{rpm}$ and $24^{\circ} \mathrm{C}$ for 5 minutes.

6- The liquid part of the centrifuged samples was poured and the pellets attached to the side walls were left.

7- The samples were placed on the sections of the robot and isolation was commenced.

4.5.b. Amplification of the $16 \mathrm{~S}$ rRNA region with PCR

The region synthesizing $16 \mathrm{~S}$ rRNA, which has an important role in bacterial systematics, was selected and amplified using universal primers (27F forward 5'- AGA GTT TGA TCC TGG CTC AG -3', 1492R backward 5'- GGT TAC CTT GTT ACG ACT T -3') under laboratory conditions.

The preparation of the PCR reaction: $30 \mu$ reaction; Using $3 \mu \mathrm{l} 10$ x PCR buffer, $0.6 \mu \mathrm{ldNTPs}, 0.3 \mu \mathrm{l} 50 \mu \mathrm{M}$ primer, $0.3 \mu \mathrm{l} 50 \mu \mathrm{M}$ primer, $1.2 \mu \mathrm{lDMSO}, 1.8 \mu \mathrm{IgCl}_{2}, 0.3 \mu \mathrm{l} 5$ unit/ $\mu \mathrm{l}$ Taq DNA polymerase and $21.5 \mu \mathrm{l}$ sterile pure water, $29-\mu$ l reaction mixture was prepared. Lastly, $1 \mu$ lemplate DNA was added to the mixture and the final volume was brought to $30 \mu \mathrm{l}[19]$.

PCR program: The PCR program was set to denaturation at $95^{\circ} \mathrm{C}$ for 120 seconds followed by 40 cycles of denaturation at $94^{\circ} \mathrm{C}$ for 60 seconds, annealing at $53^{\circ} \mathrm{C}$ for 60 seconds and extending at $72{ }^{\circ} \mathrm{C}$ for 120 seconds followed by extending at $72^{\circ} \mathrm{C}$ for 5 minutes [19].

Electrophoresis of 16S rRNA PCR products: $50 \mathrm{ml}$ 1XTAE buffer was added to $0.6 \mathrm{gr}$ agarose. The mixture was boiled in a microwave oven until obtaining a clear appearance. The agarose gel was cooled to $50{ }^{\circ} \mathrm{C}$ or to a temperature that won't burn hands and $0.6 \mu \mathrm{l}$ gel red chemical was added to the agarose gel and the gel was poured into the electrophoresis gel bath with installed combs. After waiting to make sure the gel was frozen, the combs were carefully removed from the gel. 1XTAE buffer was placed in the electrophoresis tank so that the gel surface was completely covered. To the first well in the gel, $8 \mu \mathrm{l}$ of the DNA marker was loaded and the sample was loaded to the other well.

Electrophoresis gel setup: The sample was run at 90 Volt for 60 minutes. After running, the gel was scanned using a UV light system (Gel Doc 2000 BIO RAD) and analyzed using a computer [19].

4.5.c. Collection of DNA sequence analysis and evaluation of the results Sequence analysis results were analyzed with BioEdit and converted into the Fasta format. Primer regions were identified and top and bottom parts were removed. Then, the region that was read from both sides in the middle was controlled and aligned. Moreover, using the MEGA7 program of the NCBI 
databank (with the bacteria sequences obtained with the accession number) the sequence results were compared in accordance with the Neighbor Joining cluster analysis and the phylogenetic tree was drawn.

\subsection{Measurement of enzymatic activity}

In the phytase activity measurements, activity measurement was performed for all supernatants obtained in each stage. The ranges in which phytase was active were determined. In the activity measurements, $250 \mu \mathrm{L}$ substrate was added to $100 \mu \mathrm{L}$ enzyme solution and the mixture was vortexed. Then, the mixture was placed in the water bath at $50^{\circ} \mathrm{C}$ for 10 minutes to allow reaction. To stop the reaction, $500 \mu \mathrm{L} 10 \%$ TCA was added. After a 15-minute waiting period at room temperature, $500 \mu \mathrm{L}$ coloring solution was added to the tubes. After incubation for 15 minutes, the tubes were centrifuged at $3200 \mathrm{rpm}$ for 10 minutes. Following centrifugation, the absorbance values of the samples at $700 \mathrm{~nm}$ were measured using spectrophotometry and a blind sample.

\section{6.a. Determination of the optimum $\mathrm{pH}$ for the enzyme}

For the determination of the optimum $\mathrm{pH}$ value at which the enzyme was active, $2 \mathrm{mM}$ sodium phytatecontaining substrate solutions at different $\mathrm{pH}$ values $(\mathrm{pH} 2.0-11.0)$ were prepared using the carbonate ( $\mathrm{pH} 10.0-11.0)$, Tris $(\mathrm{pH} 7.0-9.0)$, sodium citrate $(\mathrm{pH} 4.0-6.0)$ and acetate $(\mathrm{pH} 2.0-3.0)$ buffer solutions. For the determination of activity, $100 \mu \mathrm{L}$ enzyme and $250 \mu \mathrm{L}$ substrate were vortexed in a 2-ml tube. Then, the mixture was left in a water bath at $50{ }^{\circ} \mathrm{C}$ for 10 minutes to allow reaction. To stop the reaction, $500 \mu \mathrm{L}$ $10 \%$ TCA was added. After the addition of $500 \mu \mathrm{L}$ coloring solution to the tubes collected from the water bath and waiting for 15 minutes, the samples were centrifuged at 4000 rpm for 5 minutes. After centrifugation, the absorbance values of the samples at $700 \mathrm{~nm}$ were measured using spectrophotometry and a blind sample.

4.6.b. Determination of the optimum temperature for the enzyme

For the determination of the temperature at which the enzyme showed optimum activity, $10{ }^{\circ} \mathrm{C}, 20^{\circ} \mathrm{C}$, $30{ }^{\circ} \mathrm{C}, 40^{\circ} \mathrm{C}, 50^{\circ} \mathrm{C}, 60^{\circ} \mathrm{C}, 70^{\circ} \mathrm{C}, 80^{\circ} \mathrm{C}$ and $90^{\circ} \mathrm{C}$ were selected. A water bath was used for temperature measurements. For the activity measurements, $100 \mu \mathrm{L}$ of the enzyme and $250 \mu \mathrm{L}$ of the substrate were mixed and the standard activity measurement method was followed.

\section{Declarations}

\section{Authors' contributions}

ND and SMK conceived and planned the experiments. SMK, KTC, SU, and EC carried out the experiments. ND, SMK, KTC, SU and EC contributed to sample preparation. ND, SMK, KTC, SU and EC contributed to the interpretation of the results. ND. took the lead in writing the manuscript. All authors provided critical feedback and helped shape the research, analysis and manuscript. All authors read and approved the final manuscript.

\section{Funding}

Not applicable.

\section{Availability of data and materials}


The datasets used and/or analysed during the current study are available from the corresponding author on reasonable request.

\section{Ethics approval and consent to participate}

Not applicable.

\section{Consent for publication}

Not applicable.

\section{Competing interests}

The authors declare that they have no competing interests.

\section{References}

1. Yavuz HA. Türkiye'de Tarımsal Biyoteknoloji İnovasyon Sistemi, Yüksek Lisans Tezi, Sosyal Bilimler Enstitüsü, Marmara Üniversitesi. 2013.

2. Akkaya, A, Pazarlıoğlu N. 21. Yüzyılın Anahtar Teknolojisi: Beyaz Biyoteknoloji”. Kırıkkale Üniversitesi Bilimde Gelişmeler Dergisi, 2012,1,22.

3. Thieman WJ, Palladino MA, Biyoteknolojiye Giriş, Palme yayıncılık, Ankara 2013,2,9,123.

4. Karataş M. Moleküler Biyoloji/Bakteri Genetiği. Nobel Akademik Yayıncılık. Ankara. 2012, 251.

5. Andersson RA, Kõiv V, Norman-Setterblad, C, \& Pirhonen, M. Role of RpoS in virulence and stress tolerance of the plant pathogen Erwinia carotovora subsp. carotovora. Microbiology. 1999,145(12), 3547-3556.

6. Saygılı H, Sahin, F, Aysan Y. Fitobakteriyoloji, Meta Basım Matbaaclık, İzmir, Türkiye. 2006.

7. Woese CR. Bacterial Evolution. Microbiol.Rev. 1987,51, 221-271.

8. Woese CR, Stackebrandt E, Macke TJ, Fox GE. A Phylogenetic Definition of the Major Eubacterial Taxa. Syst.Appl.Microbiol. 1985,6, 143-151.

9. Bottger EC. Rapid Determination of Bacterial Ribosomal RNA Sequences by Direct Sequencing of Enzymatically Amplified DNA. FEMS Microbiol. Lett. 1989,65,171- 176.

10. Tortoli E. Impact of Genotypic Studies on Mycobacterial Taxonomy: The New Mycobacteria of the 1990s. Clin.Microbiol.Rev. 2003,16,319-354.

11. Harmsen D, Karch H. 16S rDNA for Diagnosing Pathogens: a Living Tree. ASM News. 2004,70,19-24.

12. Clarridge JE. Impact of $16 \mathrm{~S}$ rRNA Gene Sequence Analysis for Identification of Bacteria on Clinical Microbiology and Infectious Diseases. Clin. Microbiol. Rev. 2004,17,840-862.

13. Powar VK. Jagannathan V Purification and properties of phytate-spesific phosphatase from Bacillus subtillis. J. Bacteriol. 1982,151, 1102- 1108. 
14. Pandey AG, Szakacs CR, Soccol JA, Rodriguez-Leon AT. Production, purification and properties of microbial phytases. Bioresource Technol. 2017, 203-217.

15. Wulandari R, Sari EN, Ratriyanto A, Weldekiros H, Greiner R. Phytase-Producing Bacteria from Extreme Regions in Indonesia. Brazilian Archives of Biology and Technology. 2015,58,5,711-717.

16. Vohra A. Satyanarayana T. Phytases: Microbial sources, production, prufication, and potential biotechnological applications. Critical Reviews in Biotecnology, 2003,23,1,29-60

17. Arda M, Temel Mikrobiyoloji. Medisan Yayın. 2000, 46, 548.

18. Harley JP, Prescott LM. Laboratory exercises in microbiology. Fifth Edition New York: The McGraw-Hill Companies. 2002, 466.

19. Barış Ö. Erzurum İlindeki Mağaralarda Damlataşı Oluşumunda Etkili Bakterilerin İzolasyonu, Karakterizasyonu ve Tanısı. Doktora Tezi. Fen Bilimleri Enstitüsü. Atatürk Üniversitesi. 2009.

20. Adıgüzel A. Bazı Termal Tesislerden Alınan Su Örneklerinden İzole Edilen Termofilik Bakterilerin Moleküler Karakterizasyonu. Atatürk Üniversitesi, Fen Bilimleri Enstitüsü, Doktora Tezi. Erzurum. 2006, 122.

21. Lane DJ, Pace B, Olsen GJ, Stahl DA, Sogin ML, Pace NR. Rapid determination of 16 S ribosomal RNA sequences for phylogenetic analyses. PNAS. 1985,82,6955-6959.

22. Kane MD, Poulsen, LK, StahI DA. Monitoring the Enrichment and Isolation of Sulfate-Reducing Bacteria by Using Oligonucleotide Hybridization Probes Designed from Environmentally Derived 16S rRNA Sequences. Applied and Environmental Microbiology. 1993, 59,3,682-686.

23. Vandamme P, Pot B, Gillis M, De Vos P, Swings J. Polyphasic Taxonomy, a Consensus Approach to Bacterial Systematics, Microbiol. Rev. 1996, 60, 407-438.

24. Woese CR. Interpreting the universal phylogenetic tree. PNAS, 2000,97,15, 8392-8396.

25. Mora RR, Amann R. The species concept for prokaryotes. FEMS Microbiology Reviews. 2001,25, 3967.

26. Martin AP. Phylogenetic Approaches for Describing and Comparing the Diversity of Microbial Communities. Applied and Environmental Microbiology, 2002, 68,8, 3673-3682.

27. Dworkin M, Falkow S, Rosenberg E, Schleifer KH, Stackebrandt E. The Prokaryotes A Handbook on the Biology of Bacteria. Third Edition. Springer Science, 7000 p (7-volume-set), New York, USA. 2006.

28. Sarıbuğa, E. Lactobacillus plantarum ve Lactobacillus acidophilus Bakterilerinden Fitaz Enziminin Kısmen Saflaştıııması Ve Bazı Kinetik Özelliklerinin Belirlenmesi. Yüksek lisans tezi, Fen Bilimleri Enstitüsü, Atatürk Üniversitesi. 2013.

29. Tran TT, Hashim SO, Gaber Y, Mamo G, Mattiasson B, HattuKaul R. Thermostable alkaline phytase from Bacillus sp. MD2: Effect of divalent metals on activity and stabilitiy, Journal of Inorganic Biochemistry. 2011, 1000-1007.

30. Erkan K. 2014. Mikrobiyal Fitaz Üretimine Ve Aktivitesine Etkili Parametrelerin Belirlenmesi. Yüksek Lisans Tezi, Fen Bilimleri Enstitüsü, Hacettepe Üniversitesi.

31. Temiz, A. Genel Mikrobiyoloji Uygulama Teknikleri. Hatipoğlu Yayınevi, Ankara. 2000. 
32. Leloğlu N, Erdoğan N. Mikrobiyoloji Laboratuvar Yöntemleri. Atatürk Üniversitesi Yayınları No: 549, Erzurum. 1979.

33. Tarakçıoğlu S. Erzurum Ilıca Kaplıcalarından Alınan Su Örneklerinden Termofilik Bakterilerin İzolasyonu, İdentifikasyonu ve Bacillus Thermoamylovorans ST-10 İzolatından Lipaz Enziminin Saflaştırılması Ve Karekterisazyonu. Yüksek Lisans Tezi, Fen Bilimleri Enstitüsü Atatürk Üniversitesi. 2016.

\section{Figures}

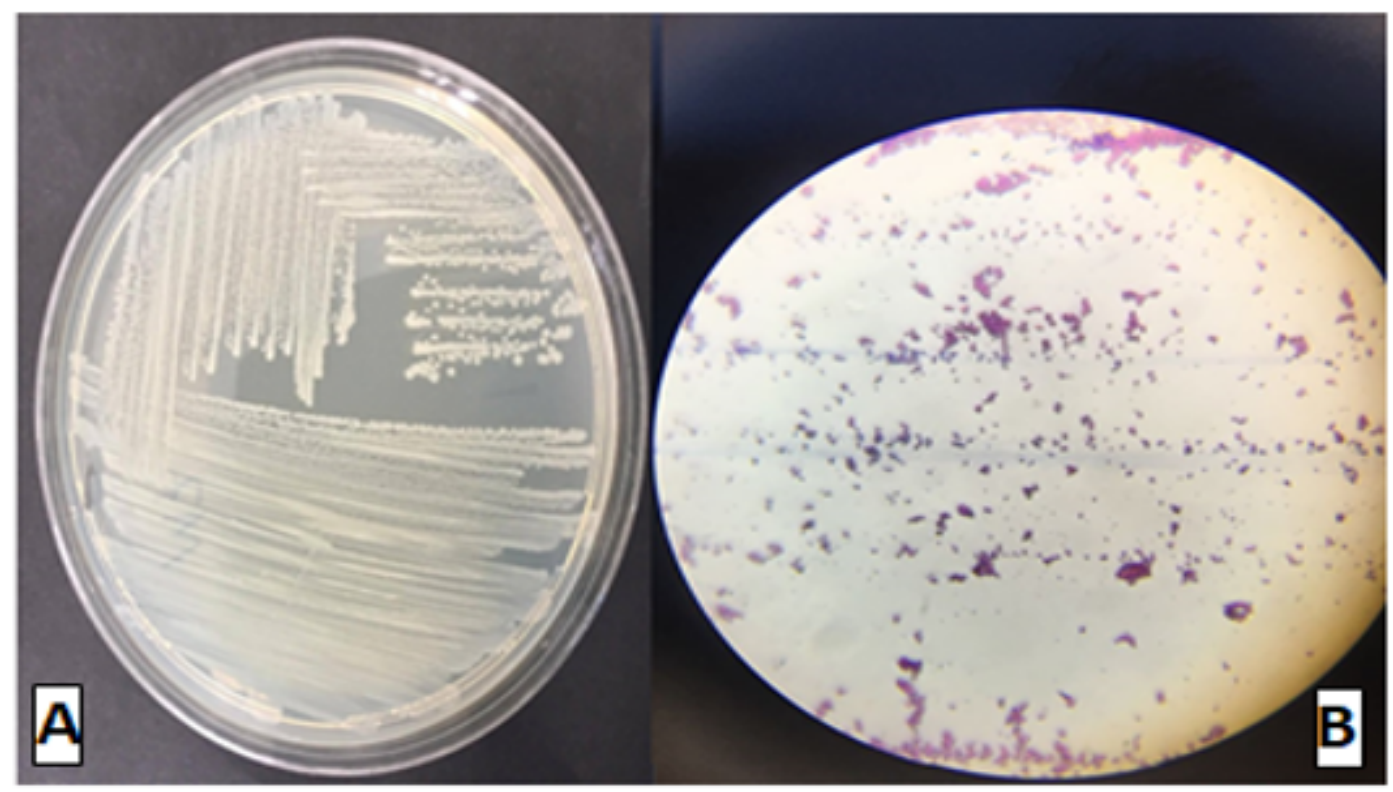

Figure 2

The colony and cell morphology of P. carotovorum *A. Petri image B. cell morphology $(10 * 40)$ 


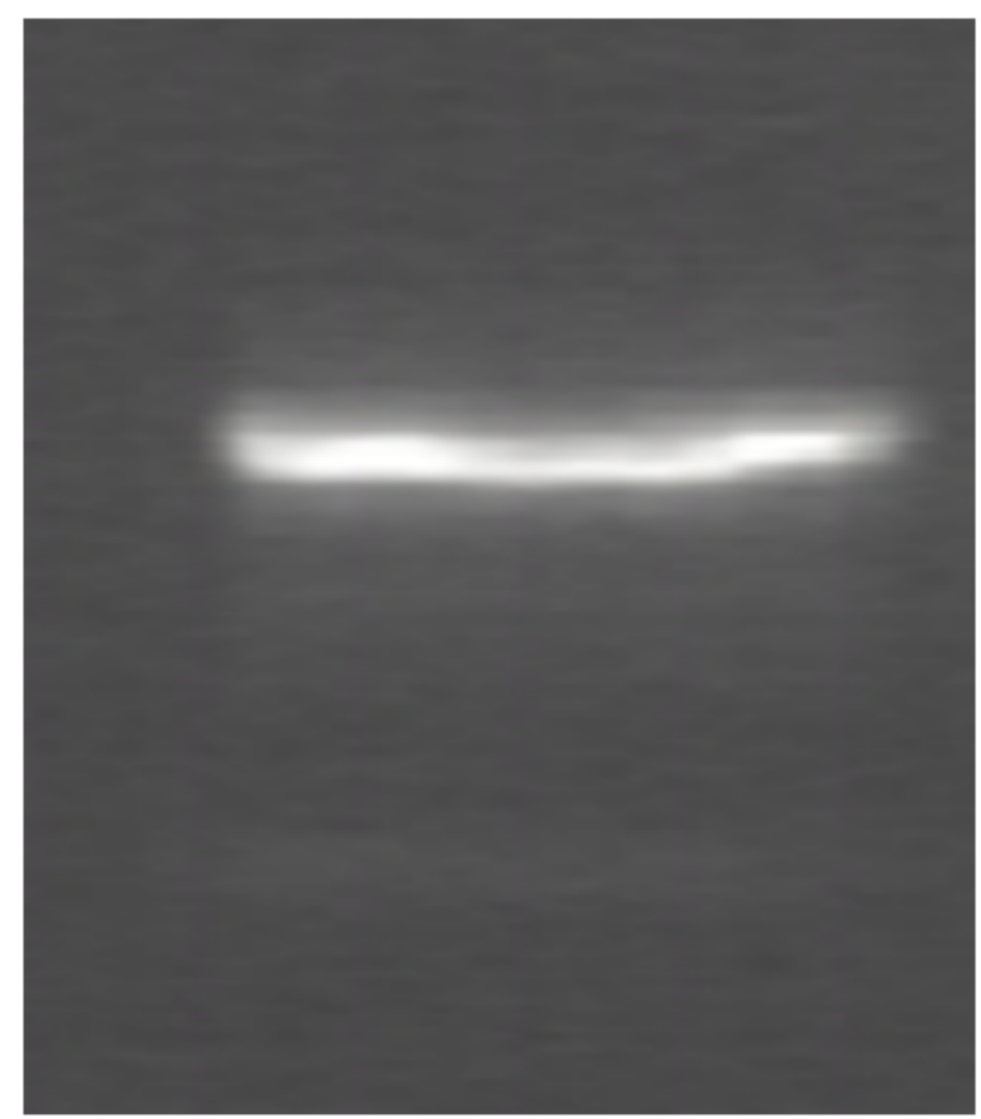

Figure 3

Gel image after DNA isolation 


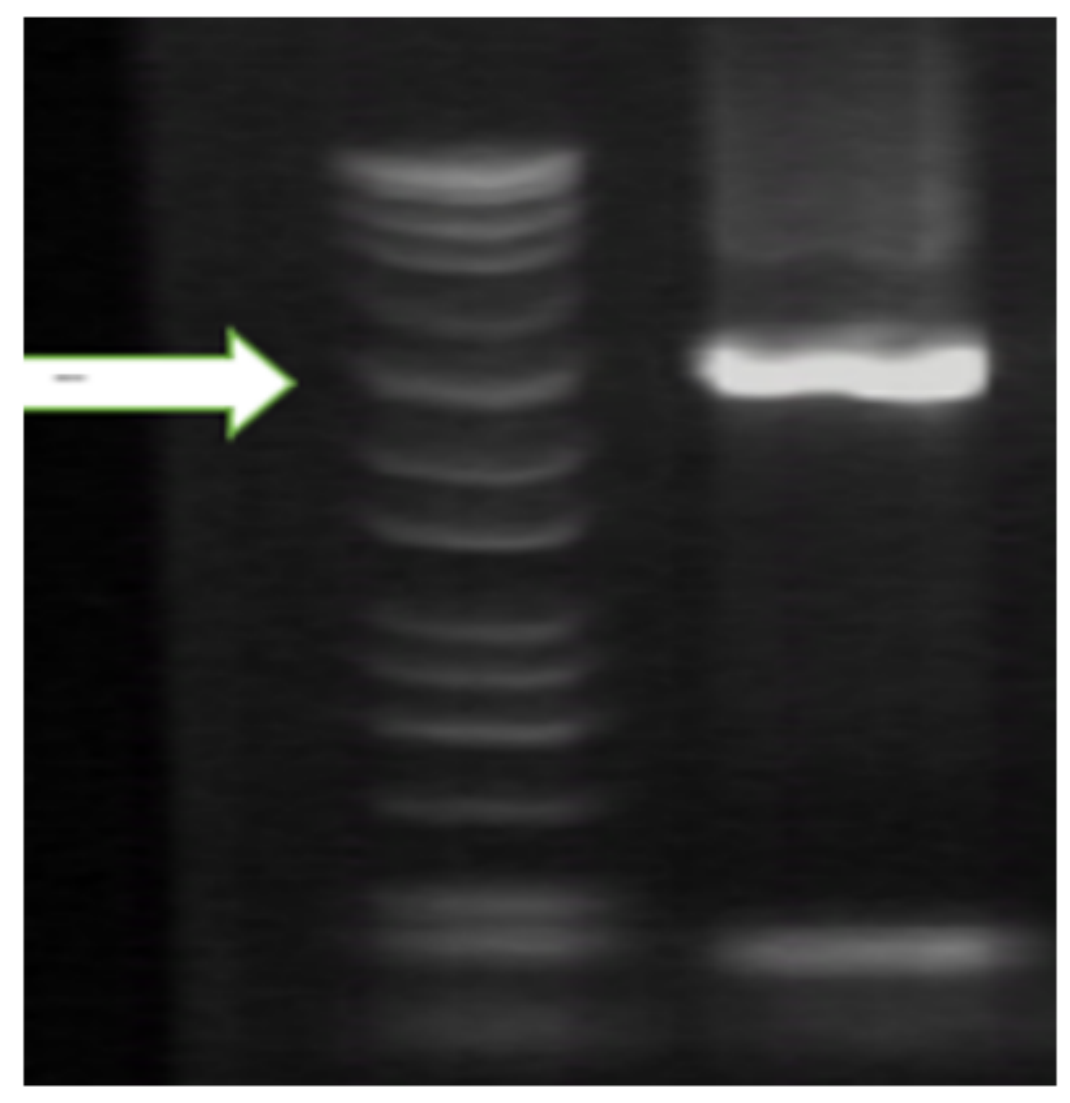

Figure 6

Gel image of the PCR results *Marked region indicates $1400-1500$ bp. 
GCTTGCTCTTTGGGTGACGAGCGGCGGACGGGTGAGTAATGTCTGGGAAACTGCCTGATG GAGGGGGATAACTACTGGAAACGGTAGCTAATACCGCATAACCTCGCAAGAGCAAAGAG GGGGACCTTCGGGCCTCTCGCCATCAGATGTGCCCAGATGGGATTAGCTAGTAGGTGAGG TAATGGCTCACCTAGGCGACGATCCCTAGCTGGTCTGAGAGGATGACCAGCCACACTGGA ACTGAGACACGGTCCAGACTCCTACGGGAGGCAGCAGTGGGGAATATTGCACAATGGGC GCAAGCCTGATGCAGCCATGCCGCGTGTGTGAAGAAGGCCTTCGGGTTGTAAAGCACTTT CAGCGAGGAGGAAGGCGGTAAGGTTAATAACCTTATCGATTGACGTTACTCGCAGAAGA AGCACCGGCTAACTCCGTGCCAGCAGCCGCGGTAATACGGAGGGTGCAAGCGTTAATCG GAATGACTGGGCGTAAAGCGCACGCAGGCGGTCTGTTAAGTTGGATGTGAAATCCCCGG GCTTAACCTGGGAACTGCATTCAAAACTGACAGGCTAGAGTCTTGTAGAGGGGGGTAGA ATTCCAGGTGTAGCGGTGAAATGCGTAGAGATCTGGAGGAATACCGGTGGCGAAGGCGG CCCCCTGGACAAAGACTGACGCTCAGGTGCGAAAGCGTGGGGAGCAAACAGGATTAGAT ACCCTGGTAGTCCACGCTGTAAACGATGTCGATTTGGAGGTTGTGCCCTTGAGGCGTGGC TTCCGGAGCTAACGCGTTAAATCGACCGCCTGGGGAGTACGGCCGCAAGGTTAAAACTCA AATGAATTGACGGGGGCCCGCACAAGCGGTGGAGCATGTGGTTTAATTCGATGCAACGC GAAGAACCTTACCTACTCTTGACATCCAGAGAATTAGCTAGAGATAGCTGAGTGCCTTCG GGAACTCTGAGACAGGTGCTGCATGGCTGTCGTCAGCTCGTGTTGTGAAATGTTGGGTTA AGTCCCGCAACGAGCGCAACCCTTATCCTTTGTTGCCAGCGATTCGGTCGGGAACTCAAA GGAGACTGCCGGTGATAAACCGGAGGAAGGTGGGGATGACGTCAAGTCATCATGGCCCT TACGAGTAGGGCTACACACGTGCTACAATGGCGTATACAAAGAGAAGCGACCTCGCGAG AGCAAGCGGACCTCATAAAGTACGTCGTAGTCCGGATTGGAGTCTGCAACTCGACTCCAT GAAGTCGGAATCGCTAGTAATCGTAGATCAGAATGCTACGGTGAATACGTTCCCGGGCCT TGTACACACCGCCCGTCACACCATGGGAGTGGGTTGCAAAA

Figure 8

Sequence analysis results of the $16 \mathrm{~S}$ rRNA gene region from the P. carotovorum isolate 


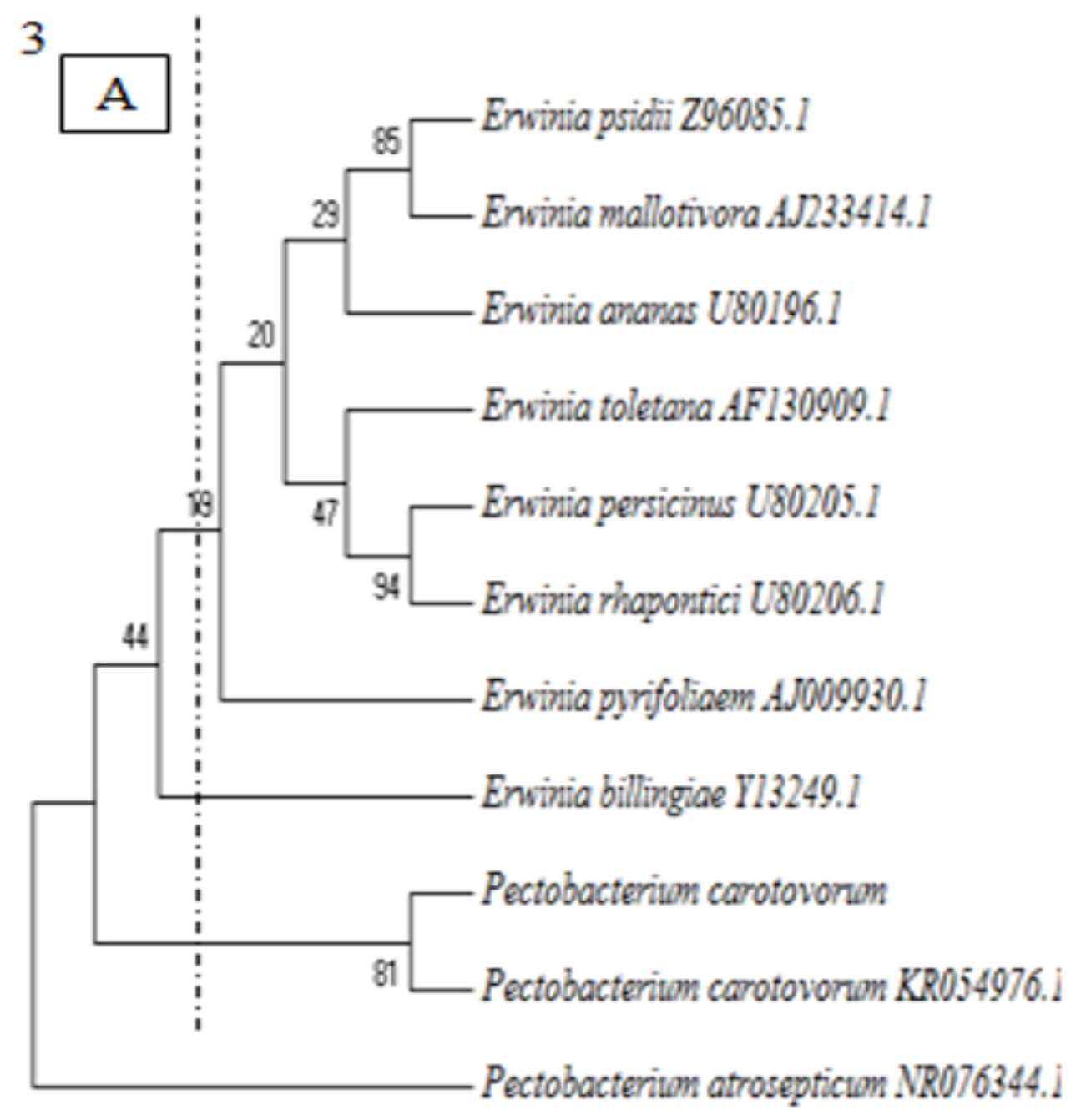

Figure 10

Determination of the location of P. carotovorum on the phylogenetic tree 


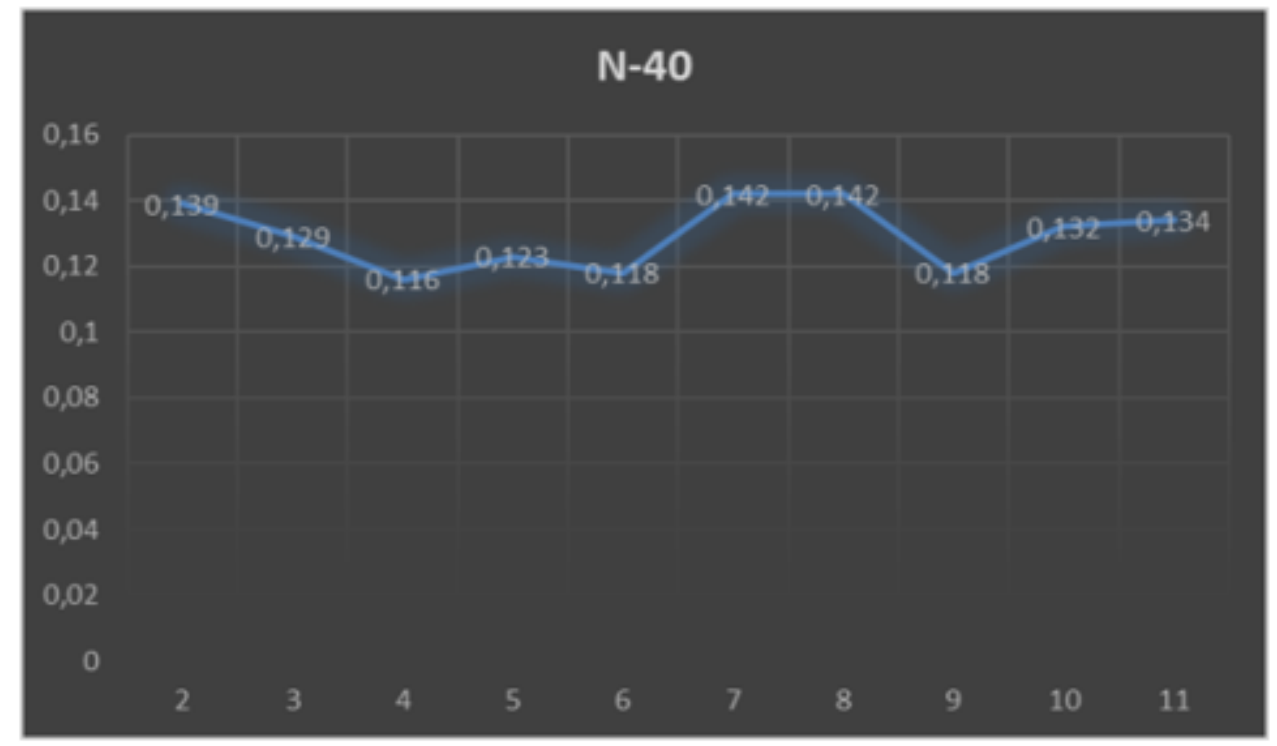

\section{Figure 11}

Effects of $\mathrm{pH}$ on the enzymatic activity of the extracellular phytase obtained from P. carotovorum

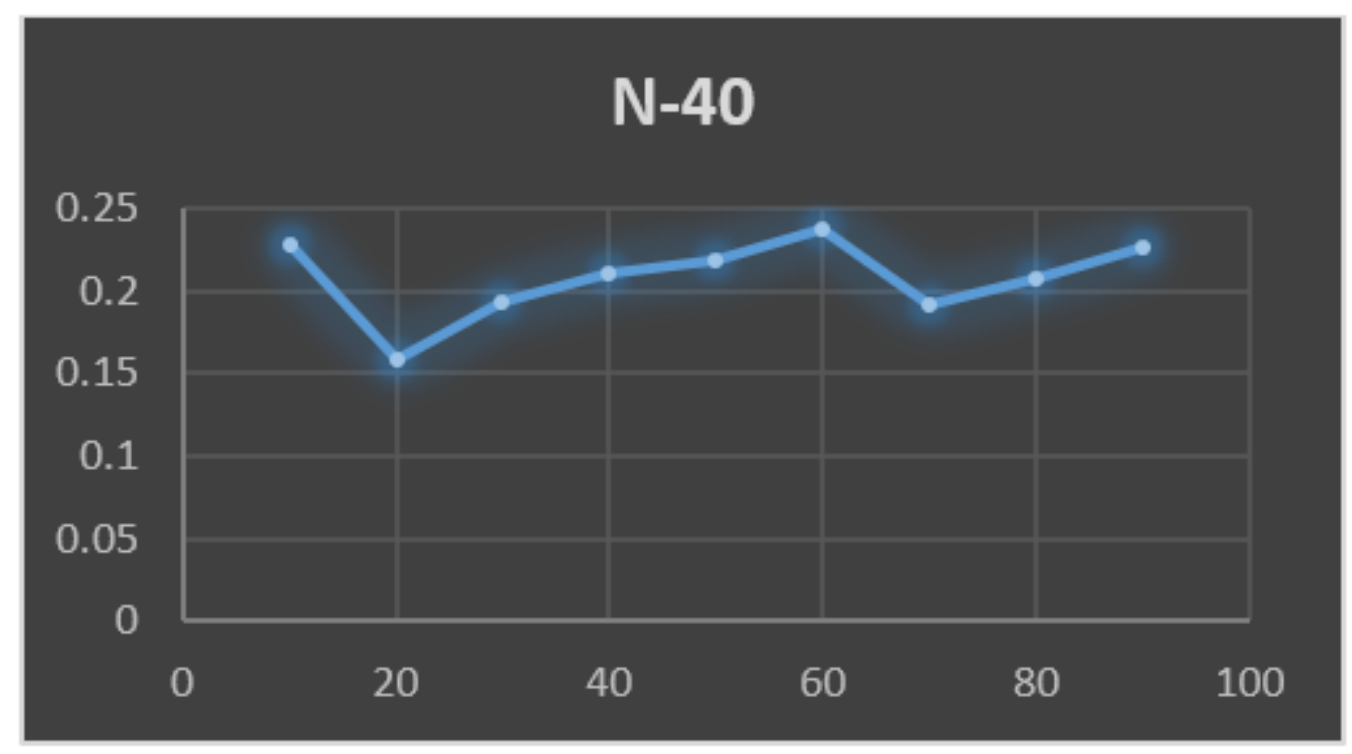

\section{Figure 13}

Effects of temperature on the enzymatic activity of the phytase that was obtained extracellularly and purified from P. carotovorum 